\title{
SETS (Science, Environment, Technology, and Society) Vision Thematic Learning Model in Improving Disaster Material Understanding of Elementary School Students
}

\author{
Setyo Eko Atmojo ${ }^{1, *}$, Taufik Muhtarom², Beny Dwi Lukitoaji ${ }^{1}$ \\ ${ }^{1}$ Department of Elementary School Teacher Education, Universitas PGRI Yogyakarta, Indonesia \\ ${ }^{2}$ National Dong Hwa University, Taiwan
}

Received July 21, 2020; Revised October 28, 2020; Accepted November 11, 2020

\section{Cite This Paper in the following Citation Styles}

(a): [1] Setyo Eko Atmojo, Taufik Muhtarom, Beny Dwi Lukitoaji, "SETS (Science, Environment, Technology, and Society) Vision Thematic Learning Model in Improving Disaster Material Understanding of Elementary School Students," Universal Journal of Educational Research, Vol. 8, No. 12, pp. 6919 - 6924, 2020. DOI: 10.13189/ujer.2020.081258.

(b): Setyo Eko Atmojo, Taufik Muhtarom, Beny Dwi Lukitoaji (2020). SETS (Science, Environment, Technology, and Society) Vision Thematic Learning Model in Improving Disaster Material Understanding of Elementary School Students. Universal Journal of Educational Research, 8(12), 6919 - 6924. DOI: 10.13189/ujer.2020.081258.

Copyright $\bigcirc 2020$ by authors, all rights reserved. Authors agree that this article remains permanently open access under the terms of the Creative Commons Attribution License 4.0 International License

\begin{abstract}
The purpose of this research is to determine the effect of the thematic learning model with SETS (Science, Environment, Technology, and Society) vision on the understanding of disaster material in elementary school students. This type of research is a quasi-experimental design. The sample was obtained using a purposive sampling technique, namely four elementary schools prone to earthquake disasters in the Bantul Regency area of Yogyakarta, Indonesia. Two schools (SD Piyungan and SD Tulung) as the experimental group and two schools (SD Karanggayam and SD Segoroyoso) as the control group. Based on the results of the t-test, post-test data obtained a t-value of 5.781>t table of 1.998, which means that there are differences in understanding students' disasters between the experimental group and the control group. The results of the calculation of the gain score indicate that the experimental group had an increased score at a high level ( $\mathrm{g}>70$ ) while the control group increased at a moderate level $(0.3 \leq g \leq 0.7)$. This study concludes that the application of the thematic learning model with the SETS (Science, Environment, Technology, and Society) vision has a practical effect on improving the understanding of disaster material for elementary school students.
\end{abstract}

Keywords Learning Model, Thematic Learning, SETS Vision, Disaster Learning Material

\section{Introduction}

Natural conditions in the last ten years continue to decline. The decline in natural conditions is caused by two factors, namely factors originating from humans and factors originating from the universe itself. Humans are the main actors responsible for the destruction of the universe. Human activities that tend to dominate and take the benefit as much as possible from nature have caused various changes and damage to nature in the past decade. The impact of human activities that are not environmentally friendly, one of which is an increase in the earth's surface temperature or better known as global warming.

The Indonesian archipelago's geographical position is unique, making Indonesia one of the areas most vulnerable to disasters. Indonesia, which consists of islands, has a very high potential for disasters and also varies significantly from the aspect of disaster types [1]; [2]. Application of plate tectonic theory to the Indonesian archipelago explains that an Indonesian archipelago is a place of collision with the crust of the earth. It is the collision of the Eurasian / Southeast Asian Plate, the Pacific, and the Dutch East Indies. Besides, the complexity of demographic, social, and economic conditions in Indonesia contributes to the 
high level of community vulnerability to the threat of disasters and the lack of community capacity to handle disasters, resulting in a high risk of disasters in Indonesia. Based on data obtained from interviews, observations, and distribution of questionnaires in schools and communities in earthquake-prone areas, it is known that one of the areas that have a high level of vulnerability to earthquakes is in Bantul Regency, Yogyakarta. Tectonically, the area of Yogyakarta and its surroundings is an area with a relatively high level of seismic activity in Indonesia. This condition is caused by the area adjacent to the plate collision zone in the Indonesian Ocean. Besides being very prone to earthquakes due to tectonic plate collision activity, the Yogyakarta area is also prone to earthquakes due to local fault activities on land. Such tectonic conditions make the area of Yogyakarta and its surroundings an active and involved seismic area.

Based on these conditions, it is necessary to understand good disaster material for the community and students in this disaster-prone region. One effort that can be done is through learning in schools. The school that has the most population and has resistance in a long time is the primary school. One of the lessons that can be used to improve students' understanding of material disaster is thematic learning with the SETS vision (Science, Environment, Technology, and Society). SETS visual learning combines the elements of science, environment, technology, and society in learning so that it can be used to improve understanding of disaster material for elementary school students.

\section{Methods}

This research is experimental research with a quasi-experimental design type. The sample stabilization technique used was purposive sampling by taking four schools in disaster-prone areas of Bantul Regency, Yogyakarta, Indonesia. This research was conducted in January 2020 until March 2020. The complete research design can be seen in Table 1 .

Table1. Research Design

\begin{tabular}{|c|c|c|c|}
\hline Class & Pre Test & Treatment & Post Test \\
\hline SD Piyungan & E1 & $\mathrm{x}$ & E3 \\
\hline SD Tulung & E2 & $\mathrm{x}$ & E4 \\
\hline SD Karanggayam & K1 & o & K3 \\
\hline SD Segoroyoso & K2 & o & K4 \\
\hline
\end{tabular}

Information:

K1 and K2: Pre Test on Control Group

E1 and E2: Pre Test on Experiment Group

o: Control Group Learning (Regular Thematic)

$\mathrm{x}$ : Experimental Group Learning (Themed Vision SETS)

K3 and K4: Control Group's Post Test

E3 and E4: Experiment Group’s Post Test
The data collected in this study are data about elementary school students' understanding of natural disaster material. Indicators of understanding of disaster material for elementary school students and data collection methods can be seen in Table 2.

Table 2. Indicators of Understanding Elementary School Students' Disaster Material and Data Collection Techniques.

\begin{tabular}{|c|c|c|c|}
\hline Indicator & $\begin{array}{c}\text { Collection } \\
\text { Technique }\end{array}$ & Instrument & $\begin{array}{c}\text { Analysis } \\
\text { Technique }\end{array}$ \\
\hline $\begin{array}{c}\text { Shows the } \\
\text { distribution of } \\
\text { the disaster area }\end{array}$ & Observation & $\begin{array}{c}\text { Observation } \\
\text { sheet }\end{array}$ & $\begin{array}{c}\text { Descriptive } \\
\text { percentage }\end{array}$ \\
\hline $\begin{array}{c}\text { Identify the } \\
\text { characteristics } \\
\text { of the disaster }\end{array}$ & Observation & $\begin{array}{c}\text { Observation } \\
\text { sheet }\end{array}$ & $\begin{array}{c}\text { Descriptive } \\
\text { percentage }\end{array}$ \\
\hline $\begin{array}{c}\text { Responsive } \\
\text { when disaster } \\
\text { strikes }\end{array}$ & Observation & $\begin{array}{c}\text { Observation } \\
\text { sheet }\end{array}$ & $\begin{array}{c}\text { Descriptive } \\
\text { percentage }\end{array}$ \\
\hline $\begin{array}{c}\text { Skilled in } \\
\text { finding a way } \\
\text { out of the } \\
\text { classroom when } \\
\text { a disaster occurs }\end{array}$ & Observation & $\begin{array}{c}\text { Observation } \\
\text { sheet }\end{array}$ & $\begin{array}{c}\text { Descriptive } \\
\text { percentage }\end{array}$ \\
\hline $\begin{array}{c}\text { Skilled in } \\
\text { finding safer } \\
\text { shelter when a } \\
\text { disaster occurs }\end{array}$ & Observation & $\begin{array}{c}\text { Observation } \\
\text { sheet }\end{array}$ & $\begin{array}{c}\text { Descriptive } \\
\text { percentage }\end{array}$ \\
\hline
\end{tabular}

\section{Results and Discussion}

The SETS visionary thematic learning model refers to the 2013 curriculum and is also a part of the 2013 curriculum. It has a position as a complement to the competencies. It also already exists in the Core Competencies and Basic Competencies in the 2013 curriculum. Competencies that complement the Core Competencies and Basic competence in the 2013 curriculum in this learning model understand competencies related to understanding disaster material in this study divided into three competencies, namely mitigation, adaptation, and responsibility competencies towards natural disasters. The SETS visionary thematic learning model is implemented in class $\mathrm{V}$ in learning on theme nine sub-theme 2.

The SETS visionary thematic learning model emphasizes the steps that must be taken in classroom learning activities. In implementing the thematic learning model SETS vision, there is a learning syntax that must be done. The thematic learning syntax with SETS vision consists of six stages of activities. The first stage is the organization and orientation. The second stage is concept formation. The third stage is the application and strengthening of concepts, the fourth stage is adapting concepts, the fifth stage is Planning and making decisions, and the sixth stage is SETS-based Evaluation. The thematic Learning Activities Phase of the SETS vision can be seen in Table 3. 
Table 3. The thematic Learning Activities Phase of the SETS vision

\begin{tabular}{|c|c|}
\hline $\begin{array}{c}\text { Stage 1: Organization and } \\
\text { Orientation }\end{array}$ & Stage 4: Concept Adaptation \\
\hline $\begin{array}{c}\text { Associate } \\
\text { Observe }\end{array}$ & Simulate Concepts \\
\hline Stage 2: Concept Formation & $\begin{array}{c}\text { Stage 5: Planning and } \\
\text { Deciding }\end{array}$ \\
\hline $\begin{array}{c}\text { Gathering Information } \\
\text { Ask }\end{array}$ & $\begin{array}{c}\text { Plan action } \\
\text { Practicing disaster based on } \\
\text { concept }\end{array}$ \\
\hline $\begin{array}{c}\text { Stake 3: Application and Concept } \\
\text { Strengthening }\end{array}$ & Stake 6:Evaluation \\
\hline $\begin{array}{c}\text { Associate } \\
\text { Communicating }\end{array}$ & $\begin{array}{c}\text { Assess / Evaluate } \\
\text { understanding of concepts }\end{array}$ \\
\hline
\end{tabular}

Based on Table 3, it can be seen that in the six syntactic activities, this learning model consists of ten phases or steps in learning activities that can be called ten $\mathrm{M}$.

The results of the thematic learning implementation of SETS vision in the experimental group schools showed positive results. It can be seen from the results of the t-test post-test score where the $t$ value was 5.781 greater than $t$ table 1.998, which means that there were differences in understanding of disaster material between the experimental groups with a control group. This difference in results is due to the implementation of the SETS visionary thematic learning. Where the thematic learning SETS vision makes it easy for students to receive learning material, this SETS visionary learning combines four elements, namely science, environment, technology, and society [3]; [4]; [5]; [6]. In this research, the thematic learning with SETS vision has the element of science as the main element in learning. This element of science serves to equip students with sufficient knowledge about the phenomenon of natural disasters that have occurred and signs of natural change seen from the side of science. This element of science is then followed by the environment, which serves to show students to be able to adapt when environmental conditions need to be watched out and avoided if at any time a disaster occurs. The technology element is given to students to provide provisions about technologies that can be used to detect a disaster so that it can bring the right response. The societal element plays a role in giving students knowledge about how to adapt. It can be as a response to the community before a disaster occurs, when a disaster occurs and after a disaster.

SETS visionary learning is implemented in elementary school students with features including syllabus, lesson plans, teaching materials, Student Worksheets, media and evaluation tools. The difference in learning that is implemented with similar learning that already exists lies in the integration of disaster material with themes and sub themes that exist in primary schools. If learning is developed by [7]; [8]; [9]; [10]; [11] teaches disaster in an integrated manner in the Natural Sciences material in grades IV, V and VI of primary schools and grades VII, VII and IX of junior high school and focuses on how teachers teach integrated disaster. Then this implied learning will complement existing learning of the same type by focusing on the thematic integration of disasters. Integration is carried out on the themes of Natural Sciences, Indonesian Language, Social Sciences, Civics and Religion.

Based on the results of the increased test, it is known that the experimental group had better improvement than the control group. The gain score test results can be seen in Table 4.

Table 4. Test Results for Improving Understanding of Elementary School Student Disaster Materials

\begin{tabular}{|c|c|c|c|c|c|}
\hline Group & $\begin{array}{c}\text { Pre } \\
\text { Test }\end{array}$ & $\begin{array}{c}\text { Post } \\
\text { Test }\end{array}$ & Gain & $\begin{array}{c}\text { N } \\
\text { gain }\end{array}$ & Criterion \\
\hline $\begin{array}{c}\text { Control 1 (SD } \\
\text { Karanggayam) }\end{array}$ & 43,25 & 62,78 & 19,55 & 0,34 & Medium \\
\hline $\begin{array}{c}\text { Control 2 (SD } \\
\text { Segoroyoso) }\end{array}$ & 41,55 & 66,38 & 25,23 & 0,43 & Medium \\
\hline $\begin{array}{c}\text { Experiment 1 } \\
\text { (SD Piyungan) }\end{array}$ & 41,33 & 82,74 & 41,41 & 0,73 & High \\
\hline $\begin{array}{c}\text { Experiment 2 } \\
\text { (SD Tulung } \\
\text { Pundong } \\
\text { Bantul) }\end{array}$ & 40,73 & 84,55 & 43,83 & 0,74 & High \\
\hline
\end{tabular}

Based on Table 4, it can be seen that the experimental group implementing thematic learning with SETS vision has a high increase in understanding of disaster material. While the control group implementing regular thematic learning has an increased understanding of disaster material at a moderate level. This difference is caused by the thematic learning with SETS vision, making it easy for students to organize disaster learning materials in class. This better organization of material can be seen from the teaching materials used in class. Teaching materials used to integrate natural disaster material are seen from the elements of science, environment, technology, and society. Students can easily understand it because it has often been found around them. Learning materials that are contextually packed and close to students will be more easily accepted by students [12]; [13]; [14]; [15]; [16]; [17]; [18]. This also happened to the implementation of the thematic SETS vision learning where students were more receptive to disaster material because it was packaged in an organized and contextual manner to increase understanding of disaster material higher than the control group.

The thematic learning model with SETS vision is implemented in the experimental group while the control group uses conventional thematic learning methods. From the results of the implementation, it is known that the mastery of the concept of disaster material in the experimental group can be seen in Table 5 . 
Table 5. Mastery of Disaster Material Concepts

\begin{tabular}{|c|c|c|c|c|c|c|c|c|}
\hline \multirow{2}{*}{ Indicator } & \multicolumn{5}{|c|}{ Meeting } & \multirow{2}{*}{ Total } & \multirow{2}{*}{ Percentage } \\
\cline { 2 - 9 } & M.1 & M.2 & M.3 & M.4 & M.5 & M.6 & & 86,66 \\
\hline Shows the distribution of the disaster area & 15 & 15 & 18 & 18 & 18 & 20 & 104 & 93,33 \\
\hline Identify the characteristics of the disaster & 16 & 18 & 18 & 20 & 20 & 20 & 112 & 81,66 \\
\hline Responsive when disaster strikes & 12 & 12 & 18 & 18 & 18 & 20 & 89 & 88,33 \\
\hline $\begin{array}{c}\text { Skilled in finding a way out of the classroom when a } \\
\text { disaster occurs }\end{array}$ & 16 & 16 & 18 & 18 & 18 & 20 & 106 & 96,66 \\
\hline $\begin{array}{c}\text { Skilled in finding safer shelter when a disaster } \\
\text { occurs }\end{array}$ & 18 & 18 & 20 & 20 & 20 & 20 & 116 & 89 \\
\hline Percentage Average & 77 & 79 & 88 & 91 & 92 & 100 & 527 & 89,33 \\
\hline
\end{tabular}

The results of the implementation of the thematic learning model with SETS vision in the experimental group in Table 5 show that the average percentage of students' management of disaster material is $89.33 \%$, which is in the high category. Meanwhile, the average mastery of disaster material in every aspect reaches more than $80 \%$. The lowest disaster material is responsive when a disaster occurs at $81.33 \%$. The low mastery of this aspect is due to the students' lack of understanding on how the most appropriate steps to deal with disasters during the initial meeting of learning activities using thematic learning models with SETS vision, namely in the first and second lessons.

In addition to the syntax material organization, the thematic learning model SETS vision also provides a real learning experience better than regular thematic learning. Real and good learning experiences can improve students' understanding [19] [20]; [21]; [22]; [23]; [24]; [25]. In implementing thematic learning with SETS vision, students directly carry out the learning steps starting from observing the environment to practicing rescue steps when a disaster occurs. This has led to an increased understanding of students in the higher experimental group. This is in line with the opinion [26]; [27]; [28]; [29] which states that learning by practicing will make it easier for students to understand the material and remember it for a longer time.

SETS vision gives color to a person's perspective in seeing and understanding something, in which everything is understood to have the SETS element, which has a reciprocal effect as a whole, which can be seen compared to if the same object was not observed with the SETS vision [30]; [31]; [32]. The SETS visionary thematic learning model is a thematic learning model that organizes thematic material and discusses it from science, the environment, technology, and society by integrating disaster material in it. The implications of SETS based and approached learning, if implemented thoughtfully, will undoubtedly benefit various parties, the students themselves, educators, and the community [33]; [34]; [35]. Furthermore, the SETS vision and approach enables the maintenance of positive values of education, religion, culture, and character [36]. Application of SETS-based learning at the elementary school level and equivalent, students whose ages range from 6-12 years (normal conditions) have different abilities in capturing the visual message. Therefore, educators are expected to use more straightforward language when conveying the meaning of this vision and when discussing its application in the learning process with students according to the student's age. Likewise, when taking examples to show how to use the SETS vision, it should start from tangible objects that are close to their daily lives. Examples of everyday life around students will make it easier for students to understand when it ultimately has to be related to the concepts they want to be taught to students [37];[38].

\section{Conclusions}

Based on the test results, it can be concluded that the implementation of the thematic SETS vision affects improving the understanding of disaster material for elementary school students. This can be seen from the results of the t-test, which shows the value of $t$ count $=$ 5.781 $>\mathrm{t}$ table $=1.998$, which means that there is a difference between the experimental group and the control group. This result is supported by the results of the gain score test, which shows that the $\mathrm{N}$-gain score in the experimental group ( $g>0.70$ ) increases the understanding of disaster material in the high category. In comparison, the control group has a score of $\mathrm{N}$ gain $(0.3 \leq g \leq 0.7)$, which means an increase in understanding of disaster material in the medium category.

\section{REFERENCES}

[1] R. Afrian, J. Hariadi, B. Akob, and Z. R. Islami, "Local Culture Inventory for Disaster Mitigation Learning,” IOP Conf. Ser. Earth Environ. Sci., vol. 412, no. 1, 2020, doi: 10.1088/1755-1315/412/1/012017.

[2] A. Mustadi and Atmojo S. E., "Student's disaster literation in 'sets' (Science environment technology and society) disaster learning,” Elem. Educ. Online, vol. 19, no. 2, pp. 
667-678, 2020, doi: 10.17051/ilkonline.2020.693118.

[3] P. Prasojo, T. Prastowo, and M. Ibrahim, "International Journal of Multicultural and Multireligious Understanding SETS Based Science Teaching Materials with Guided Inquiry Learning Model to Improve Learning Outcomes in Optical Geometry Materials,” pp. 10-18, 2020.

[4] Atmojo, S. E., Rusilowati, A., \& S. I. A. Dwiningrum, "Characteristics and validity of SETS-based disaster learning models,” 2020, doi: 10.1088/1742-6596/1567/4/04 2064.

[5] Nurkaenah, W. Isnaeni, and B. Subali, "Influence of SETS Science Learning Program Towards Scientific Literacy Improvement,” J. Prim. Educ., vol. 8, no. 1, pp. 59-66, 2019, [Online]. Available: https://journal.unnes.ac.id/sju/index.ph p/jpe/article/view/25230.

[6] H. Y. Salisah and S. Wardani, "Journal of Innovative Science Education Application of LKS Vision of Science, Environment, Technology , and Society in Learning Science to Improve Students ' Science Literacy of MTs,” vol. 7, no. 2, pp. 382-390, 2018.

[7] A. Rusilowati and A. Binadja, "Mitigasi Bencana Alam Berbasis Pembelajaran Bervisi Science Environment Technology and Society,” J. Pendidik. Fis. Indones., vol. 8, no. 1, pp. 51-60, 2012, doi: 10.15294/jpfi.v8i1.1994.

[8] R. Umaira, A. G. Haji, and H. Rahmatan, "Science Environmental Technology and Society- based Module Development on Petroleum Chemistry to Enhance Student Learning Achievement,” Int. J. Innov. Sci. Math., vol. 7, no. 2, pp. 88-98, 2019.

[9] S. Ramadhan, E. Sukma, and V. Indriyani, "Environmental education and disaster mitigation through language learning," IOP Conf. Ser. Earth Environ. Sci., vol. 314, no. 1, 2019, doi: 10.1088/1755-1315/314/1/012054.

[10] R. Murti and S. lanMathez-Stiefel, "Social learning approaches for ecosystem-based disaster risk reduction," Int. J. Disaster Risk Reduct., vol. 33, no. October, pp. 433-440, 2019, doi: 10.1016/j.ijdrr.2018.09.018.

[11] C. Wu et al., "UAV Autonomous Target Search Based on Deep Reinforcement Learning in Complex Disaster Scene," IEEE Access, vol. 7, pp. 117227-117245, 2019, doi: 10.1109/access.2019.2933002.

[12] K. M. L. Jones, "Advising the whole student: eAdvising analytics and the contextual suppression of advisor values," Educ. Inf. Technol., vol. 24, no. 1, pp. 437-458, 2019, doi: 10.1007/s10639-018-9781-8.

[13] S. Khasinah, “Classroom Action Research,” J. Pionir, Vol. 1, Nomor 1, vol. 1, no. 2, pp. 33-61, 2013, doi: 10.17977/um013v1i42017p156.

[14] I. Z. Ichsan, D. V. Sigit, M. Miarsyah, A. Ali, W. P. Arif, and T. A. Prayitno, "HOTS-AEP: Higher order thinking skills from elementary to master students in environmental learning,” Eur. J. Educ. Res., vol. 8, no. 4, pp. 935-942, 2019, doi: 10.12973/eu-jer.8.4.935.

[15] M. Hawa, Andayani, Suyitno, and N. E. Wardani, "The implementation of literary sociology learning model with contextual and spiritual quotient approach to teach literary sociology,” Int. J. Instr., vol. 12, no. 1, pp. 283-298, 2019, doi: 10.29333/iji.2019.12119a.

[16] P., S. Rochmiyati, and Z. Wijayanto, "Mathematics Learning Profile of Junior High School," PEOPLE Int. J. Soc. Sci., vol. 6, no. 1, pp. 411-421, 2020, doi: 10.20319/pijss.2020.61.411421

[17] M. Akour, H. Alsghaier, and S. Aldiabat, "Game-based learning approach to improve self-learning motivated students,” Int. J. Technol. Enhanc. Learn., vol. 12, no. 2, p. 146, 2020, doi: 10.1504/ijtel.2020.10027116.

[18] Rasmitadila, Widyasari, M. A. Humaira, A. R. S. Tambunan, R. Rachmadtullah, and A. Samsudin, "Using blended learning approach (BLA) in inclusive education course: A study investigating teacher students' perception,” Int. J. Emerg. Technol. Learn., vol. 15, no. 2, pp. 72-85, 2020, doi: 10.3991/ijet.v15i02.9285.

[19] Kintoko and P. Jana, "Development of Mathematics Module on the Material of Flat Side Space Building in DIY Culture-Based,” J. Phys. Conf. Ser., vol. 1254, no. 1, 2019, doi: 10.1088/1742-6596/1254/1/012072.

[20] J. Hoxmeier and M. M. Lenk, "Service-Learning in Information Systems Courses: Community Projects that Make a Difference,” J. Inf. Syst. Educ., vol. 14, no. 1, pp. 91-100, 2003.

[21] C. C. Hyun et al., "Implementation of contextual teaching and learning (CTL) to improve the concept and practice of love for faith-learning integration," Int. J. Control Autom., vol. 13, no. 1, pp. 365-383, 2020.

[22] I. M. Arnawa, Yerizon, S. Nita, and R. T. Putra, “Development of students' worksheet based on apos theory approach to improve student achievment in learning system of linear equations,” Int. J. Sci. Technol. Res., vol. 8, no. 4, pp. 287-292, 2019.

[23] P. Y. A. Dewi and K. H. Primayana, "Effect of Learning Module with Setting Contextual Teaching and Learning to Increase the Understanding of Concepts,” Int. J. Educ. Learn., vol. 1, no. 1, pp. 19-26, 2019, doi: 10.31763/ijele.v1i1.26.

[24] R. E. Simamora, S. Saragih, and H. Hasratuddin, "Improving Students' Mathematical Problem Solving Ability and Self-Efficacy through Guided Discovery Learning in Local Culture Context," Int. Electron. J. Math. Educ., vol. 14, no. 1, pp. 61-72, 2018, doi: 10.12973/iejme/3966.

[25] M. E. Putri, . M., and D. R. S. Saputro, "The Effect of Application of REACT Learning Strategies on Mathematics Learning Achievements: Empirical Analysis on Learning Styles of Junior High School Students,” Int. J. Educ. Res. Rev., pp. 231-237, 2019, doi: 10.24331/ijere.518065.

[26] L. B. Wiltbank, K. R. Williams, L. Marcinia, and J. L. Momsen, "Contrasting cases: Students' experiences in an active learning biology classroom," CBE Life Sci. Educ., vol. 18, no. 3, pp. 1-11, 2019, doi: 10.1187/cbe.19-01-0006.

[27] I. Martiningsih, Lisdiana, and S. M. E. Susilowati, "Development of Module Based on Scientific Contextual Additives Material to Increase Learning Outcomes and Science Process Skills in Junior High School,” J. Innov. Sci. Educ., vol. 8, no. 2, pp. 128-137, 2019.

[28] S. M. Kromka and A. K. Goodboy, “Classroom storytelling: 
using instructor narratives to increase student recall, affect, and attention," Commun. Educ., vol. 68, no. 1, pp. 20-43, 2019, doi: 10.1080/03634523.2018.1529330.

[29] R. Butarbutar, R. Uspayanti, N. Manuhutu, and S. T. Palangngan, "Analyzing of puzzle local culture-based in teaching english for young learners," IOP Conf. Ser. Earth Environ. Sci., vol. 343, no. 1, 2019, doi: 10.1088/1755-1315/343/1/012208.

[30] Hairida and L. Hadi, “Improving student’s critical thinking skills through SETS vision learning," USEJ Unnes Sci. Educ. J., vol. 6, no. 2, pp. 1571-1566, 2017.

[31] S. E. Bibri and J. Krogstie, "On the Social Shaping Dimensions of Smart Sustainable Cities : ICT of the New Wave of Computing for Urban Sustainability," Sustain. Cities Soc., vol. 29, no. 7491, pp. 219-246, 2017, doi: 10.1016/j.scs.2016.11.004.

[32] K. Crippen, Designing for Collaborative Problem Solving in STEM Cyberlearning Innovations in Science Education and Technology Series editor, no. January. 2018.

[33] L. P, S. Sapriya, and K. Komalasari, "Development of Critical Thinking Ability Through Sets Based Learning Approach: An Action Research on Grade XI IPA 1 SMAN 5
Dumai,” J. Int. Conf. Proc., vol. 3, no. 1, pp. 136-149, 2020 doi: 10.32535/jicp.v2i4.788.

[34] Usmeldi, R. Amini, and S. Trisna, “The development of research-based learning model with science, environment, technology, and society approaches to improve critical thinking of students,” J. Pendidik. IPA Indones., vol. 6, no. 2, pp. 318-325, 2017, doi: 10.15294/jpii.v6i2.10680.

[35] N. Shukla and S. Kiridena, "A fuzzy rough sets-based multi-agent analytics framework for dynamic supply chain configuration,” Int. J. Prod. Res., vol. 54, no. 23, pp. 6984 6996, 2016, doi: 10.1080/00207543.2016.1151567.

[36] C. Salawane, "Development of Lecture Model in Disaster Science Volcanic Dust by LiTMas Approach,” vol. 443, no. Iset 2019, pp. 480-483, 2020.

[37] Supriyadi, A. Rusilowati, S. Linuwih, A. Binadja, and C. Salawane, "Science environment technology and society approach learning to improve natural disaster mitigation literacy,” J. Phys. Conf. Ser., vol. 1387, no. 1, 2019, doi: 10.1088/1742-6596/1387/1/012119.

[38] Degirmenci, Y., \&Ilter, I. (2017). An Investigation into Geography Teachers' Use of Current Events in Geography Classes. Universal Journal of Educational Research, 5(10), 1806-1817. 